\title{
NON-MODERNIZATION: \\ POWER-CULTURE TRAJECTORIES AND \\ THE DYNAMICS OF POLITICAL INSTITUTIONS
}

\author{
Daron Acemoglu \\ James A. Robinson \\ Working Paper 29007 \\ http://www.nber.org/papers/w29007 \\ NATIONAL BUREAU OF ECONOMIC RESEARCH \\ 1050 Massachusetts Avenue \\ Cambridge, MA 02138 \\ July 2021
}

We are grateful to Jennifer Pan for her suggestions and advice and Juan Camilo Yamin for this research assistance. We also thank David Stasavage for his comments. The views expressed herein are those of the authors and do not necessarily reflect the views of the National Bureau of Economic Research.

NBER working papers are circulated for discussion and comment purposes. They have not been peer-reviewed or been subject to the review by the NBER Board of Directors that accompanies official NBER publications.

(C) 2021 by Daron Acemoglu and James A. Robinson. All rights reserved. Short sections of text, not to exceed two paragraphs, may be quoted without explicit permission provided that full credit, including $\odot$ notice, is given to the source. 
Non-Modernization: Power-Culture Trajectories and the Dynamics of Political Institutions Daron Acemoglu and James A. Robinson

NBER Working Paper No. 29007

July 2021

JEL No. N10,O10,P16

\begin{abstract}
$\underline{\text { ABSTRACT }}$
Modernization theory is a cornerstone of much of political science, despite the mounting evidence against its predictions. In this paper, we argue that the theory's failings are rooted in predictions that are not conditioned on history and cultural configurations. We outline a theory in which the interplay of the distribution of political power and cultural configurations lead to three distinct self-reinforcing paths of political development, with very different state-society relations, institutions, and economic structures. These are paths to Despotic, Absent and Shackled leviathans. The role of cultural configurations, made up of attributes in a society's culture set, is critical in legitimizing the social arrangements in each path. For example, a Despotic Leviathan, as in China, cannot be understood without appreciating how Confucian culture has been used to bolster a worldview in which rulers are supposed to be virtuous and regular people are discouraged from political participation. We argued that this interpretation is not inherent to Confucian thought, but has to be understood as an endogenous outcome along the trajectory to the Despotic Leviathan. None of the three different paths we highlight support modernization theory. Under the Absent Leviathan, there is no economic modernization. Under the Despotic Leviathan, economic growth bolsters the existing regime and its supporting cultural configuration, with no tendency towards democracy or associate political changes. Under the Shackled Leviathan, there are dynamics leading to economic growth and political changes with greater bottom-up participation. Nevertheless, the causation does not go from the former to the latter, and these changes are critically dependent on cultural and political entrepreneurship in order to formulate and popularize new cultural configurations and institutionalize political changes.
\end{abstract}

\title{
Daron Acemoglu
}

Department of Economics, E52-446

Massachusetts Institute of Technology

77 Massachusetts Avenue

Cambridge, MA 02139

and NBER

daron@mit.edu

James A. Robinson

University of Chicago

Harris School of Public Policy

and Department of Political Science

1307 East 60th Street

Chicago, Illinois 60637

and NBER

jamesrobinson@uchicago.edu 


\section{Introduction}

"The rule of Virtue may be compared to the Pole Star, which stays in its place while the myriad stars pay it homage" Xi Jinping speaking to Communist Party members, 2017. ${ }^{1}$ President Xi was quoting Confucius as a justification for his continued rule at the helm of the Communist Party. His notion of Virtue leaves no room for civil society or democratic participation, something already limited in China and becoming much more constricted during his rule. To many political scientists this is a challenge. Modernization theory, most influentially articulated by Lipset (1959), is one of the cornerstones of modern political science and predicts that as societies become richer, more educated and economically more modernized, they should also experience a particular path of political institutions - become more democratic, respect civil and human rights more, and develop several other societal features we commonly associate with Western democracies. ${ }^{2}$ China's economy has been modernizing rapidly. It has the largest middle class anywhere in the world (estimated as 730 million people in 2016, see Kharas and Dooley, 2016), and has reached 8.1 years of schooling on average. ${ }^{3}$ Many aspects of its economy are more modern than in the US, for example the majority of its citizens already use electronic payments and the most advanced communication technologies. Its income per capita has exceeded US \$13,000 in 2011 prices which makes it $20 \%$ richer than the UK in 1945 (data from Bolt and van Zanden, 2020), a critical period during this country's political history, when it was implementing the Beveridge Report's recommendations in building a modern welfare state backed by a highly democratic political structure.

Is China's stubborn authoritarian rule the nail in the coffin of modernization theory? Not necessarily to its defenders. First, they may claim that China is the exception that proves the rule (Treisman, 2020, p. 246). Second, they may claim that true modernization in China is delayed because of various historical factors (the Cultural Revolution, Confucian culture or some remnants of Communist beliefs). For example, Treisman (2020) proposes a "conditional modernization" theory where culture, amongst other factors, can delay the onset of modernization. Indeed, to Lipset himself, modernization was partly a cultural process. As a country becomes richer, more educated and more modern, Lipset argued, its values change and this is the leitmotif of its democratization.

The problem with modernization theory is in fact deeper: it is inadequate for thinking about these issues because it posits a link between economics and politics that is not conditional on institutions and culture and that presumes a definite endpoint - for example, an "end of history"

\footnotetext{
${ }^{1}$ https://www.straitstimes.com/opinion/the-confucian-roots-of-xi-jinpings-policies

${ }^{2}$ Other important works on modernization theory include Apter (1967), Huntington (1968) and Rostow (1971).

${ }^{3}$ http://hdr.undp.org/en/data
} 
as in Fukuyama (1989). In practice, the relationship between economics and politics and how economic and political development impact each other cannot be separated from these institutional and cultural factors, and this dependence means that there is no unique endpoint towards which all societies inexorably head.

This perspective is related to the framework we developed in a number of recent works (Acemoglu and Robinson, 2017, 2019), where we argued that historical and various structural forces shape how state-society relations develop. We pointed out that three broad clusters of long-run economic and political institutions are possible. In the first (Absent Leviathan), the state is weak and societal collective action and various norms are strong and constrain political hierarchy. In the second (Despotic Leviathan), the state is strong and crushes and further impairs an already-weak society. In the third (Shackled Leviathan), there is a balance between state and society's capacities, and this enables their co-evolution towards greater strength for each and also undergirds a very different type of state - simultaneously powerful and still accountable and responsive to society. Economic modernization is almost impossible under the Absent Leviathan. It is possible under the Despotic Leviathan, and under some circumstances it can proceed rather rapidly. But it will not bring democracy or accountable behavior by rulers and bureaucrats. The positive feedback between political institutions and economic development is only a feature of the Shackled Leviathan. As a result, the same economic changes in, say, South Korea will have fundamentally different implications than when they happen in China. ${ }^{4}$ These insights, though formulated in a different way and yielding different implications than in the previous literature, are nevertheless related to some classic arguments in political theory. Machiavelli proposed similar ideas more than 500 years ago, identifying a related trichotomy and writing: "the people are everywhere anxious not to be dominated or oppressed by the nobles, and the nobles are out to dominate and to oppress the people. These opposed ambitions bring about one of three results: a principality, a free city, or anarchy" (1961, p. 67).

Missing from our previous framework, as well as from Machiavelli's thought, is the role of culture. Different state-society relations are not just bolstered by economic and political contests (as modeled in Acemoglu and Robinson, 2017). They are also interwoven with particular worldviews that emerge and legitimize prevailing institutions and distributions of political power. This is the focus of the current paper. We build a framework where the exact interplay between institutions, culture and politics is shaped by historical and structural factors, and this interplay can go in

\footnotetext{
${ }^{4}$ This highly context-specific effects of economic modernization is confirmed by the cross-national econometric results of Acemoglu et al. (2008, 2009) see also Acemoglu and Robinson (2018).
} 
diametrically-opposed directions depending on these factors.

The key new element in this paper turns on the concept of a cultural configuration. We argue, building on Acemoglu and Robinson (2021), that many societies have a fairly stable culture set consisting of (cultural) attributes, which determine such things as the importance of hierarchy, the role of family and gender roles, the higher ideals (such as virtue and honor) that are valued, with specific types of rituals and relevant customs and traditions. These attributes can be combined into different cultural configurations, each with different meanings for individuals and societies and each providing justifications for distinct political arrangements and social hierarchies. Hence, the Despotic Leviathan — and why under its auspices, economic growth will not automatically bring democratic institutions - cannot be fully understood without appreciating the cultural configuration that emerges and convinces people that rule by virtuous leaders is legitimate and ordinary people should not challenge them and should not strive to have their voices heard. It also provides interpretations that push people towards accepting the virtue of such leaders. Vitally, however, our framework does not claim (nor is it true) that such attitudes are ingrained and unchangeable. A given culture set can generate many different cultural configurations, and as the political balance of power and other structural conditions change, a new cultural configuration can emerge, with very different justifications for politics, sometimes rather swiftly.

The Chinese case powerfully illustrates these ideas and elucidates why modernization theory is not a useful framework. Indeed, cultural factors are central in the Chinese equilibrium, which still heavily depends on Confucian philosophy. In Confucius's view, the best organization of society had powerful leaders and a government that did not need to have any accountability, let alone democracy. Elsewhere, Confucius says "When the Way prevails in the world, commoners do not debate matters of Government" (Confucius, 2003, 16.2 p. 193). Rather, government would operate best when leaders cultivate virtue and found the Way. This Confucian philosophy has deeply influenced Chinese politics for 2,500 years throughout the vicissitudes of dynastic politics, invasions, European colonialism, economic decline, state collapse and, last but not least, communism. The famous examination system tested its aspirants on their knowledge of the Confucian classics, and now the Chinese government sponsors Confucius Institutes all over the world.

This is the basis of the view of scholars such as Huntington that China was bound to be nondemocratic given its Confucian culture, writing that "no scholarly disagreement exists regarding the proposition that traditional Confucianism was either undemocratic or antidemocratic" (1991, p. 24). Yet, the specific way in which Confucian philosophy was applied cannot be understood without considering who exercised political power in China and how. The Qin dynasty created 
the first version of the Imperial state, relying not just on Confucian ideas but also on Legalism, as articulated by Lord Shang who claimed "When the people are weak the state is strong; when the people are strong the state is weak. Hence, the state that possesses the Way devotes itself to weakening the people" (Shang Yang, 20.1, 2017, p. 79).

Here virtuous rule apparently involved weakening the people, just in case. Though the Qin triumphed by military might, the reason that this relative power balance between state and society and the institutions that have accompanied it have been so enduring in China is because basic elements of Confucian philosophy have been fused with the top-down model of government articulated by Legalism. Indeed, neither imperial rule nor the reign of the Communist Party in China can be understood without appreciating how Confucian philosophy was critical in people's lives (generating meaning, order in family relations, stable expectations and specific rituals), but at the same time how it also legitimized top-down rule. ${ }^{5}$

Crucially, however, it would also be a mistake to follow Huntington and presume that this particular legitimization of despotic rule by Confucian thought is a hardwired feature of Chinese society and politics. Rather, it has emerged and endured because the distribution of political power and political institutions have reinforced it. Put differently, China's political trajectory has created a specific type of feedback between its institutions and cultural configuration. The more empowered are the ruler and the elites, the more ingrained the cultural configuration legitimizing their rule and discouraging societal participation becomes. And in typical circular fashion, the greater is the legitimacy conferred on it, the stronger authoritarian rule becomes. Another balance of political power could have produced a very different cultural configuration. We see this in Taiwan, which has the same Confucian culture set as China, but over the last 30 years, it has combined the same attributes in a way that generated a very different cultural configuration, supporting vibrant democratic rule. It is not only that different cultural configurations, with widely differing political implications, are possible. It is also that, as we will discuss, the shift from one cultural configuration to another can be rather abrupt, which is again illustrated by Taiwan's history.

There is nothing unique about China or Confucian culture. We will encounter similar dynamics in English history, where different political philosophies were constructed from the same foundations and justified very different state-society relations and political systems. Moreover, the English case illustrates even more clearly than the Chinese one how a volte-face in cultural configuration can

\footnotetext{
${ }^{5}$ Perry $(2008,2018)$ discusses the continuities and similarities between imperial and communist ideologies of state legitimacy. Pan and Xu (2017) document there is a strong correlation between Chinese citizens beliefs in the importance of Confucianism and the extent to which they view western political institutions and rights as inappropriate in China.
} 
take place in response to changing political and economic conditions.

What does this all mean for modernization theory? As we have already hinted at, the coexistence of different political trajectories, leading to very different limiting equilibria of state-society relations, already invalidates the core precept of modernization theory. However, in our assessment, the failings of modernization theory are deeper. The exact way in which cultural configurations emerge, which we argue to be critical for understanding the nature of political power in society, shapes what economic modernization and economic growth involve and what types of social and political arrangements are viewed as legitimate. Modernization theory, by ignoring the critical role of cultural configurations and how they can endogenously remake what is and what is not feasible, may be inducing us to focus on the wrong variables as determinants of the dynamics of political institutions.

We are of course not the first ones to think about the role of culture in politics. Although cultural factors are not part of many of the seminal frameworks of political science, for example Tilly's (1990) theory of the emergence of states, Moore's (1966) theory of capitalism, fascism and communism, or more orthodox Marxist frameworks for understanding political and economic change, they have featured in a number of important contributions. For example, as we already mentioned, Huntington places a heavy emphasis on culture in his work on civilizations (1996). Culture has also played a critical role in the modern literature on nationalism and identity, for example Anderson (1983), Gellner (2009), Horowitz (2000), or Laitin (1998), and in the literature about the impact of religion on politics, as in the work by Laitin (1986), Kalyvas (1996) and Grzymala-Busse (2012, 2015). Putnam's (1993) theory of good democratic governance, building on Banfield's (1958) insights, also provides a central role to cultural factors. Finally, Almond and Verba's (1963) seminal work merges culture and political behavior in understanding the support for democracy.

Nevertheless, none of these approaches have recognized the two pillars that are at the center of our framework. The first is the malleable role of cultural configurations (and how they can be constructed from a stable culture set). Although this notion is central to much of modern sociology (e.g., work by Geertz, 1973, Swidler, 1986, DiMaggio, 1997, and Sewell, 2005), it has had less of an impact in political science. An exception is the "constructivist" research on ethnic identity, such as Posner (1995) and the essays in Chandra (2012), which studies the endogeneity of ethnic identity, but without extending the analysis to think about the malleability of culture more broadly. The second is the presence of multiple long-run trajectories, with no natural tendency for all societies to move in the same direction, develop the same type of relationship between economics and politics, 
or even respond in the same way to structural changes. ${ }^{6}$

The rest of the paper is organized as follows. The next section introduces our conceptual framework and highlights the interplay between politics and culture. The next three sections apply this framework to illustrative cases of Despotic, Absent and Shackled leviathans, starting with the Chinese case. Section V distills some of the lessons from these case studies and reevaluates modernization theory. Section VI concludes with directions for future work.

\section{Reinterpreting the Varieties of Leviathan}

We start with a framework building on Acemoglu and Robinson (2019), where very different political systems can emerge as stable long-run equilibria, bolstered by different types of state-society relations. Figure 1 illustrates the configurations we have in mind. The two axes of this figure represent two key dimensions of how a polity is organized (abstracting from several other relevant aspects for simplicity). On the vertical axis we have the capacity of the state, which summarizes both the capacity of state institutions and the ability of these institutions and elites in charge of them to impose their will and control over society. On the horizontal axis, on the other hand, we have the capacity of society, which represents the ability of society to organize (for example by solving its collective action problems) and have its voice heard (either via institutionalized means or by protests and other non-institutionalized actions). The three long-run political equilibria depicted in Figure 1 - which we call Despotic Leviathan, Absent Leviathan and Shackled Leviathan - involve different types of state institutions and different patterns of political participation by regular citizens. They also come associated with their own "basins of attraction" within which, as the illustrative trajectories indicate, dynamics gradually evolve toward those long-run institutional equilibria.

How different these trajectories are deserves some emphasis. Let us first focus on the trajectory heading towards the Despotic Leviathan, which captures a general feature of this basin of attraction. Here, the dominance of the state over society makes society become increasingly impaired and unable to organize and contest power. Interestingly, however, this trajectory also underscores that the capacity of the state will ultimately stop growing somewhere below the maximum power it can achieve. Put simply, the long run state-society configuration that emerges from these trajectories is one of great imbalance between the capacities of the state and society, but it also involves a limit

\footnotetext{
${ }^{6}$ Sociologists, such as Gorski (2003), Adams (2005), and the contributors in Steinmetz (1999), have examined the role of cultural factors in state formation. But these works have not attempted the type of broad comparative analysis that we propose here.
} 


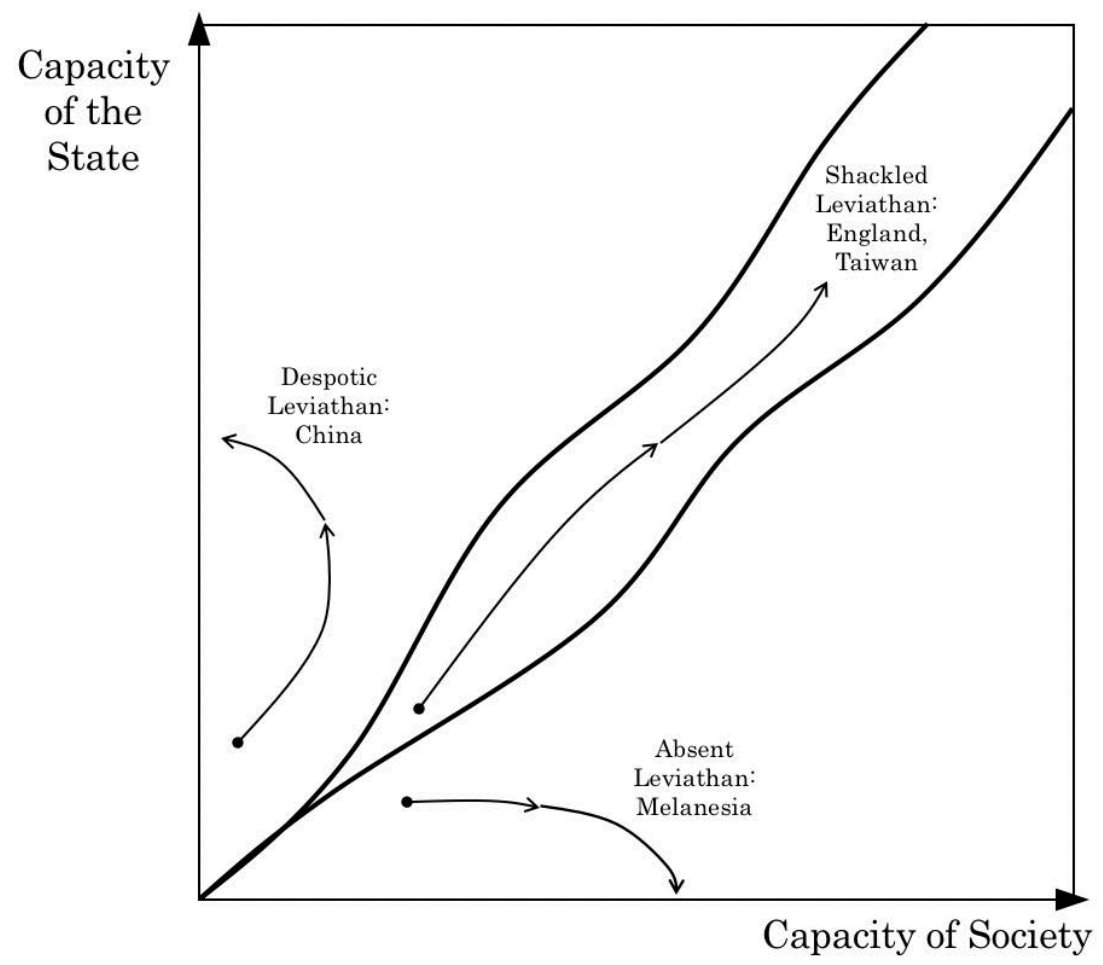

Figure 1: Varieties of Leviathan

on how powerful and capable the state becomes.

In the basin of attraction of the Absent Leviathan, we see the converse dynamics. Now society is relatively strong and this prevents political hierarchy and strong state institutions from emerging. Ultimately, any institutional arrangements that create this type of hierarchy tend to atrophy - a typical pattern we see in the history of politically decentralized societies (often called "small-scale" or maybe "stateless" societies).

In the middle corridor, something very different transpires. In contrast to the two other basins of attraction, the capacities of both state and society increase simultaneously. In Acemoglu and Robinson (2019), we interpreted this as resulting from both competition and cooperation between state and society. Competition is rooted in the fact that as the state gets more capable, it becomes harder to monitor and society needs to increase its powers in order to be able to keep up and maintain its relative situation. Cooperation is equally important: When society is capable of reigning in the state, it becomes more willing to share information and allow the state to penetrate and regulate various productive and social relations. This type of state-society balance is in fact critical for the emergence of democratic institutions, a general notion of liberty (providing protection 
and social opportunities for agency for individuals), and economic dynamism. That trajectories in this middle region are tending towards values of state capacity greater than those achieved by the Despotic Leviathan is related to these features.

A degree of self-reinforcing dynamics is apparent in all of these trajectories. For example, for the Despotic Leviathan, the stronger the state and elites become, the weaker is society. What are the roots of these self-reinforcing dynamics? Although these dynamics have some element of power begetting power due to the standard economic and political reasons (see e.g., Acemoglu and Robinson, 2012), detailed analysis of historical dynamics suggests that there is more to it. States become stronger when they are viewed as more legitimate, and when they are stronger, they tend to increase their legitimacy. Similarly, along this trajectory, it becomes accepted that citizens have less business in interfering in government affairs and there is less need for civil society organizations monitoring and pressuring elites. But some of the major tools for understanding issues of legitimacy and what is socially acceptable — social meanings, expectations, values and beliefs - are missing from this framework. Where did they come from?

This is what we would like to develop and add to the framework in the current paper. We start from the modern sociology literature in thinking about culture. Geertz defines culture as "historically transmitted pattern of meanings embodied in symbols, a system of inherited conceptions expressed in symbolic forms by means of which men communicate, perpetuate, and develop their knowledge about and attitudes towards life" (1973, p. 89). Several aspects of this definition are worth emphasizing. Most importantly, Geertz refuses the simplistic notion that culture is about stable values. Rather, culture is about interpreting the world, defining social meaning, communicating and justifying social actions. This notion of culture also clarifies that in any given society there are many different ways of creating meaning and justifying actions. This perspective is the basis of Swidler's influential work, which defines culture as:

a "toolkit" or repertoire from which actors select differing pieces for constructing lines of action. Both individuals and groups know how to do different kinds of things in different circumstances" (1986, p. 277).

Put differently, many different values, interpretations and justifications are consistent with a given culture. This is the basis of our notion of a cultural configuration which emphasizes that different configurations, with different social implications, can be produced from the same culture.

In Acemoglu and Robinson (2021), we develop this perspective further by conceptualizing the constituent elements of culture as "attributes" that are contained in a culture set and can be com- 
bined together in various different ways to produce different cultural configurations. For instance, as we will see in the next section, there are several important elements in Confucian philosophy related to the importance of virtue, tradition, rituals and hierarchy, but these can be combined in different ways, and their combinations provide different social meanings and legitimizations for different types of political arrangements.

The fluidity of a culture is pivotal here. Though in Acemoglu and Robinson (2021) an important part of the emphasis is on how fluid (malleable) different cultures may be, here we simplify matters and presume that we are dealing with sufficiently fluid cultures that allow a multitude of cultural configurations with distinct political and social implications. This opens the way specifically to what DiMaggio (1997, p. 265) emphasizes when he notes:

once we acknowledge that people behave as if they use culture strategically, it follows that the cultures into which people are socialized leave much opportunity for choice and variation.

Building on his terminology, we interpret the world as having plenty of scope for the "strategic use of culture".

What does this imply in the context of Figure 1? We start from the perspective that the true extent of self-reinforcing dynamics underlying these trajectories cannot be understood without studying how these trajectories themselves shape social meaning, values and beliefs. Put simply, the trajectory going towards the Despotic Leviathan cannot be separated from the cultural configuration that dictates that top-down rule is legitimate, rulers are virtuous or divinely empowered, and common people interfering in matters of state is inappropriate. This cultural configuration, used strategically both by leaders to further their positions and by citizens to adapt to life in a despotic polity, then makes it harder for civil society to become stronger and renders it more likely that the imbalance of power will continue. In typical self-reinforcing fashion, the longer we are in the basin of attraction of the Despotic Leviathan, the more ingrained the current cultural configuration gets, and the easier it becomes to legitimize the rule of elites - be they emperors or bosses of the Communist Party.

Likewise, in the basin of attraction of the Absent Leviathan, state institutions atrophy because the population comes to believe that any political hierarchy is dangerous, a tool in the hands of upstart individuals, and/or likely to lead to much worse outcomes along a predictable slippery slope. Analogous to what we described in the context of the Despotic Leviathan, it is difficult to escape from the orbit of the Absent Leviathan, because people increasingly view political hierarchy as 
illegitimate. As we describe below, this type of thinking becomes second nature to many individuals living in politically decentralized societies without powerful state institutions, and of course once it becomes widespread, and incorporated into their belief systems, it makes such societies likely to endure and political hierarchy and state institutions much less likely to emerge.

A very different type of cultural configuration supports the trajectories in the middle corridor, where the Shackled Leviathan emerges. Now, it is neither unacceptable for regular people to participate in politics and keep rulers accountable, nor is it illegitimate to create political hierarchy and centralized institutions. Instead, a cultural configuration with a number of distinctive aspects develops. First, differently from the trajectory supporting the Despotic Leviathan, suspicious attitudes towards those who are politically powerful endure. Though this attitude has some similarity to the politically egalitarian beliefs under an Absent Leviathan, it is very different from them, because it takes a more institutionalized form. People are willing to vote and participate in civil society organizations and other institutionalized-forms of political engagement in order to do this. Second, in partial contrast to the first, it becomes natural for people to trust impersonal institutions and accept the political hierarchy that is associated with them (think of the natural way in which many people in democratic and even semi-democratic societies accept the authority of courts, bureaucracies and political officeholders). In fact, people become willing to demand more from, and also willing delegate more to, the state.

Third and fundamentally related to the first two, a different model of political philosophy emerges: according to this model, political power emanates from the people who can then delegate it to state institutions or rulers. These rulers and institutions can become further empowered and take on greater responsibilities, but are supposed to remain accountable and act on behalf of the people. This model of "popular sovereignty" builds on and further promotes a synergy between suspicions towards political hierarchy and the willingness of people to trust and empower state institutions and the people in charge of them.

As with the trajectories in the orbits of Absent and Despotic leviathans, in this case, too, the longer we stay along the trajectory towards the Shackled Leviathan, the stronger these approaches to social meaning and political legitimacy become. For example, the stronger is society's ability to organize and have its voice heard, the more ingrained the notion of popular sovereignty becomes. Likewise, the stronger and more autonomous state institutions are, the easier it is to trust them for effectiveness and the more justifiable it is for people to actively participate in politics to control them and have their voices heard in the functioning of these increasingly powerful state institutions.

Finally, while we have emphasized the self-reinforcing relationship between the distribution of 
political power and the cultural configurations that legitimize those arrangements, our framework does not claim that these are immutable. As in Acemoglu and Robinson (2019), political, economic or demographic shocks can both reshape the basins of attraction of the different types of leviathans and shift a polity from one basin to another. Hence, historical conditions create powerful tendencies for persistence, but do not cause permanent lock-in. Cultural feedbacks enrich but do not change this picture, because the same types of shocks can induce changes in cultural configurations. As a result, our framework implies that Huntington's portrayal of Chinese culture as unchanging and unchangeable was simplistic. In contrast, we will see that it is possible for attributes to be rewired so as to generate alternative cultural configurations, support different power-culture trajectories, and legitimize very different types of state-society relations and distinct types of political institutions. In fact, major shocks that shift a society into a new basin of attraction can induce very rapid cultural change.In the rest of the paper, we go through three applications, one corresponding to each of the three types of leviathans, in order to provide more details about the interplay between politics and cultural configurations, and also highlight how cultural configurations can change in response to structural shocks. Once these additional insights are obtained, it will become much more apparent why modernization theory fails to provide an empirically accurate or useful account of the dynamics of political institutions and how we need to move beyond it.

\section{When State Dominates Society: The Despotic Leviathan}

The historical formation of the Chinese state began with the first Qin dynasty which united the country by military conquest in 221BC. This was based on a model of a top-down state micromanaging society, along the lines recommended by Lord Shang, but still drawing on Confucian philosophy. Confucius painted a picture of an ideal society held together by ritual virtue and filial piety. A famous depiction appears in the text The Great Learning:

Their thoughts being sincere, their hearts were then rectified. Their hearts being rectified, their persons were cultivated. Their persons being cultivated, their families were regulated. Their families being regulated, their States were rightly governed. Their States being rightly governed, the whole kingdom was made tranquil and happy. (Legge, 1893, pp. 358-359)

Here virtue begins in peoples' hearts and ripples up to the level of the state (Fei, 1992, pp. 62-63). The government does not need mechanisms of accountability to behave in the collective interest; this will simply be the consequence of everyone cultivating virtue. If they do not, then 
accountability would not solve the problem. The role of the specific cultural configuration bolstering top-down rule is pivotal. It would have been most probably infeasible for successive Chinese dynasties to rely on intense repression in order to control their populations. But when people are convinced that such top-down rule is legitimate, it becomes much more likely to survive.

This cultural configuration was based on a powerful synthesis of despotism and Confucianism. A telling illustration is the imperial examination system which was definitively institutionalized by the Song dynasty. In this system, the people staffing the government were chosen via three levels of examination. What was examined was knowledge of Confucian thought, and the state was able to impose its interpretation of Confucian ideas onto the people who then ran the state. The state thus reinforced a cultural configuration, legitimizing its authority.

All the same, this cultural configuration cannot be understood without recognizing the political structure in which it was embedded. As Weber noted long ago, "the basic characteristics of the [Confucian] "mentality" ... were deeply co-determined by political and economic destinies" (1951, p. 249). Or put differently, the trajectory underpinning and moving towards the Despotic Leviathan in Figure 1 is made possible by the synergy between despotic political power and a cultural configuration adapted to it.

\section{When Society Dominates the State: The Absent Leviathan}

The synergy between political power and specific cultural configurations is critical not just for the Despotic Leviathan, but also for its polar opposite, a polity with an Absent Leviathan. Because power is distributed differently, the cultural configurations that emerge and sustain economic and political relations in such societies are very different. Malinowski's ethnographic work in Melanesia elucidates some of the most salient features of politics and cultural configurations in such societies.

To illustrate the nature of these relations on the small coral island of Kitava, Malinowski relates the "myth of the flying canoe" (1922, pp. 311-316). The Kitavans decided to build canoes for a great Kula expedition, a large system of inter-island exchange. The main character in the myth, Mokatuboda, who possessed magic powers, built his canoe in the village and then flew it to the sea by magic (pp. 312-313). Mokatuboda's control of magic not only transported his canoe, but was making him a very powerful headman. According to the myth, he used magic to make it rain on his own fields and thus harvested far more crops than others. But rather than celebrating him, the Kitavans decided to stop his accumulation of power and wealth: "His brothers and maternal nephews sharpened the spear, they hit him, he died" (p. 315). 
The anti-hierarchic, intensely egalitarian attitudes illustrated by this myth are very common across politically decentralized societies that do not have state institutions. In such societies, most conflict is resolved via traditions and norms or some sort of enforced compromise, so there is less need for state institutions for dispute resolution. But how do you prevent people like Mokatuboda or chiefs or big men from becoming economically and then politically dominant? This is where egalitarianism comes in: people are not allowed to accumulate too much wealth or too much political power. This egalitarianism affects every aspect of society (see Acemoglu and Robinson, 2019). For example, trade is regulated and constricted (lest, it leads to too much accumulation). Some goods are not allowed to be bought (otherwise they confer too much status or could be used for patronage or power accumulation). In Kitava, economic institutions enmesh "the whole community into a network of reciprocal obligations and dues, one constant flow of gift and countergift" (Malinowski, 1921, p. 8). Institutions forced output to be distributed in a very equal way, and the organization of the Kula ring similarly reinforced egalitarianism.

Notably, none of this is institutionalized. It is a set of beliefs and practices that maintains this egalitarian equilibrium, and hence the cultural configuration is critical. For example, in most such societies supernatural beliefs reinforce the non-hierarchical, egalitarian social system. Those who become rich or powerful are suspected of sorcery or witchcraft (Malinowski, 1926). Though all of these practices and their implications for state-society relations are diametrically opposed to those we saw in the Chinese case, there is an important commonality: the cultural configuration is synergistic with the distribution of political power. A cultural configuration that refuses hierarchy and treats powerful men as nefarious, dangerous upstarts cannot coexist with the building of state institutions or incipient hierarchy, and the lack of such institutions further bolsters this cultural configuration. Tellingly, when the process of state-building starts in such societies, we often see powerful forces towards altering the cultural configuration (for example, as led by Shaka Zulu when he was building the early state institutions in Zululand; see Acemoglu and Robinson, 2019).

\section{When Society Balances the State: The Shackled Leviathan}

The nature of state-society relations is very different in the middle corridor in Figure 1. Here, in a process that we called the "Red Queen effect" in Acemoglu and Robinson (2019), the capacities of both state and society co-evolve: the stronger the state becomes (for example, in terms of its capacity to regulate the economy or enforce laws and rules), the more active and assertive society needs to become in order to rein it in. This is a dynamic process, involving significant institutional 
changes along the way. It is, in equal part, about politics and culture. The powers that society and citizens need to acquire in order to remain in the corridor are political, but they need to be bolstered by appropriate cultural configurations.

This dynamic can be seen in the English case, which witnessed fundamental institutional change in the 17th century. Though a monarchy, in the 16th century the country already housed a highly active citizenry, for example, with local communities organizing in various participatory ways, making demands from the central state, and sometimes resisting policies the state was attempting to impose on them (Acemoglu and Robinson, 2019, Hindle, 2000). The tradition of Germanic assemblies that were central for the island's politics before the Norman invasion still had major effects at the time (Wickham, 2016). Nevertheless, institutional means for popular participation in government were lacking.

A number of momentous changes started altering English society and economy from the middle of the 16th century. First, the capacity of the national state began to increase under Henry VII and picked up speed with Henry VIII's "Tudor Revolution of Government" (Elton, 1953). Second, as Tawney (1941) emphasized, a class of commercially-minded new farmers, the "gentry", emerged and started changing the economy after monastic lands were expropriated and then sold off by Henry VIII (Heldring, Robinson and Vollmer, 2015). Third, Atlantic and inter-oceanic trade opportunities enriched a new class of merchants and industrialists who had until then been excluded from the governing coalition of the country (Acemoglu, Johnson and Robinson, 2005, Pincus, 2009, Jha, 2015). These newly-empowered groups vied for greater political power, destabilizing the political system and paving the way to the Civil War in 1642 and later to another, albeit less disruptive, civil war culminating in the Glorious Revolution of 1688.

These epochal events that led to a constitutional monarchy and intensified political participation from a broader segment of society were not just political. They also involved the emergence of a radically new cultural configuration. At the center of this change was the notion of popular sovereignty that was articulated around the same time as the Civil War. The Levelers articulated and fought for popular participation in politics in the 1640s. Thomas Hobbes's 1651 classic, Leviathan, articulated a materialistic portrayal of the "state of nature" and a contractarian model of the creation of the state based on a "covenant". John Locke pushed this perspective further, proposing an almost modern version of popular sovereignty, whereby sovereignty rests with the people who then delegate it to a ruler on the condition that he acts in line with their interests and instructions. It is difficult to imagine how the significant increase in political participation could have taken place without this new philosophy of popular sovereignty. The emergence of these ideas 
of popular sovereignty and "resistance" (meaning, resistance to the monarchy's unchecked power) was itself rooted in the political changes brought about by the demands and revolt of newly-enriched merchants, industrialists and gentry, as Sommerville emphasizes when he writes "Talk of resistance became more common after 1640 not because of the sudden discovery of resistance theory, but because resistance had become a practical possibility" (1999, p. 75).

Hence, even though very different in nature than those that emerge under the Despotic and Absent leviathans, the trajectories in the basin of attraction of the Shackled Leviathan, too, critically depend on the interplay and synergy of politics and cultural configurations. Moreover, the more dynamic nature of the interactions between state and society inside the corridor crystallizes another key question: how do cultural configurations change? How did the notion of popular sovereignty come to be articulated and influential in 17th-century England, for example? This is the question we tackle in the next section in the context of reevaluating modernization theory.

\section{Whither Modernization Theory}

We have so far described three different types of political and social dynamics - under the auspices of, respectively, Despotic, Absent and Shackled leviathans. Do these dynamics support modernization theory?

In the case of Absent Leviathan, economic modernization is rare, because the types of economic arrangements Malinowski described in Melanesia do not encourage technological change or productivity-enhancing large-scale trade. Even accumulation of wealth and assets is constricted by the cultural configuration that tries to maintain egalitarianism. This does not completely preclude all economic modernization, since some individuals or groups can sometimes accumulate enough power or form the right coalitions to take command and, in the process, reorganize economic relations (Flannery and Marcus, 2014, Acemoglu and Robinson 2019). However, when that happens, the most likely transition is from the Absent Leviathan to the Despotic Leviathan, which does not involve institutionalizing popular political participation.

What about economic growth and modernization under the Despotic Leviathan? As the Chinese case illustrates, this is feasible. However, it very often takes the form of "despotic growth", whereby the state and elites play a defining role and their dominance over society, rather than weakening, becomes solidified. Hence, as growth under the Song dynasty and during the post-Mao era highlight, this type of economic growth does not typically bring any type of democracy or greater political participation or accountability. On the contrary, as again underscored by recent Chinese history, 
rapid growth can sometimes increase the grip of the despotic state, which gains greater legitimacy and comes to control more resources, which it can use to repress or cultivate support.

While dynamics in the basis of attraction of the Absent and Despotic leviathans provide no support for modernization theory, economic modernization and a transition towards more democratic political institutions do go hand-in-hand in the Shackled Leviathan configuration. Yet, even this type of change does not take the almost automatic form that modernization theory predicts. Changes in cultural configuration necessitate both major efforts by "cultural entrepreneurs" in order to recombine existing attributes into a new cultural configuration and intense struggles over these configurations within the population. The English case illustrates this dynamic, too.

Monarchic rule, without constitutional or participatory constraints, was justified in early modern England by a cultural configuration emphasizing the central role of obedience to authority. The roots of this can be traced to the writings of Saint Paul, who stated in Colossians 1:16: "For by him were all things created that are in heaven, and that are in earth, visible and invisible, whether they be thrones, or dominions, or principalities, or powers." This model of Pauline obedience was reinforced by Saint Augustine, whose views Ryan sums up as: "[one] would find true peace and justice only in God's kingdom. Here we must simply obey the powers that be" (2012, p. 199). The Catholic Church promoted this view, emphasizing that God's chosen rulers were communicated by the Pope. According to this model, even if rulers misbehaved, one had to be obedient because they would be judged by God. Ryan argues "The conventional view down to the sixteenth century was that if a ruler required his subjects to repudiate Christ, they did not have to comply; short of that, they had to obey" (2012, p. 199).

The social changes brought by Tudor monarchs, and especially Henry VIII, had started changing this picture, partly because of the break between the Church of England and the papacy, which meant that English kings could not appeal to the Pope's authority. It was against this background that the ideas of popular sovereignty were elaborated and articulated by cultural entrepreneurs such as Thomas Hobbes and John Locke. Entrepreneurship, we think, is an apt word in this context, because these thinkers were creating and trying to popularize a different way of conceptualizing the world - and as a result legitimizing a different set of political institutions and state-society relations (see Mokyr, 2016). In doing this, Hobbes and Locke, as well as the Levelers and others, built not just on the Bible and Christian thought, but also on ancient customs, especially ideas of participatory Germanic institutions, mentioned above. They drew on notions of popular sovereignty which had flourished in the Medieval city states of northern Italy (manifested in the writings of such scholars as Marcelius of Padua), and which became transformed in the process of the Reformation spearheaded 
by Martin Luther and Jean Calvin and "A movement toward a more overtly constitutional view of politics took place" (Ryan, 2012, pp. 342-343) (see also Skinner, 1978, Wolin, 2004).

These justifications were not accepted by all English people, however. There ensued an intense political and cultural struggle, and the English Civil War has to be viewed within this broader perspective. There was no certainty that this struggle would lead to the victory of popular sovereignty over more authoritarian ideas such as the Divine Right of Kings, propagated by the Stuart monarchs.

A major part of the struggle was about convincing the broader public of the plausibility and desirability of alternative cultural configurations, which thinkers like Hobbes and Locke achieved for popular sovereignty. Nevertheless, for these changes to be enduring, they had to be institutionalized, meaning that the institutional foundations of political power had to change in tandem. This meant a need for not just cultural but also political entrepreneurship, which we also see in this historical episode. After the Civil War the English Commonwealth was created and in 1653 England's first written constitution, the Instrument of Government, was promulgated. This was the first constitution in the world that featured explicit separation of powers between the executive and the legislative an innovation from notions of "mixed government" (Vile, 1967). These innovations ultimately took their final form after the Glorious Revolution of 1688.

Overall, the English case illustrates yet another instance of the synergy between power and culture, and also emphasizes that any path of political institutions that ended up accompanying economic changes was not an automatic process, but required intense struggle and various innovations from cultural and political entrepreneurs. So even when we see something that looks like the predictions of modernization theory in the middle corridor (while it is completely absent in the rest of Figure 1), its nature is very different than what modernization theory claims. This last point is again central: the emergence of a cultural configuration supporting political change is always contingent on the historical balance between state and society as well as cultural and political entrepreneurship. We cannot bank on the existence of such entrepreneurs in all societies and epochs, and even when they exist, their ideas may not succeed in supplanting those enshrined in the older cultural configuration backed up by the prevailing distribution of political power.

Let us finally emphasize that Figure 1 should not be read as suggesting unchanging cultures. While it is true that the cultural configuration supporting the Despotic Leviathan takes stronger root the longer the Despotic Leviathan remains in power, it never becomes completely immutable. This can be seen clearly in the case of Confucian culture. Huntington's pronouncement that Confucian culture is anti-democratic notwithstanding, Confucius's teachings were sufficiently fluid that 
they should not be viewed as rigidly authoritarian. As Goldin (2011, p. 10) observes, "Confucius wished his statements to remain fluid", and the Confucian attributes can be recombined to generate very different cultural configurations. Confucius also states: "a state cannot stand once it has lost the confidence of the people" (Confucius, 12.7, p. 128), which can clearly be given a democratic interpretation - a bad government will lose the confidence in the people and then can be brought down by the people.

This is exactly what happened in Taiwan, which has an even stronger Confucian culture than mainline China (not having suffered the Cultural Revolution). In the decades that followed the communist revolution, Taiwan, too, was ruled despotically by Chiang Kai-shek's Kuomintang (KMT). But the political equilibrium started shifting as a result of social and economic changes that followed land reforms and industrialization (which may themselves have been triggered by KMT's efforts to deliver growth and a more egalitarian distribution of income in order to stave off any support for communism) and a new integration into the international system. By the 1990s, demand for a more democratic regime was growing in the population and forcing political change in Taiwan. Confirming our interpretation, changing politics brought rapid changes in the cultural configuration, but using the same basic attributes of the Confucian culture set. Political participation was justified with the Confucian idea that non-virtuous leaders cannot stand. In the words of Fetzer and Soper's (2012): "the Confucian tradition is flexible ... it allows for more than one interpretation, and it can be used as a basis for democracy and human rights" (p. 3).

Could the Taiwanese case be interpreted as an example of modernization theory? The answer is once again no. Although economic modernization was one of the root causes of the changes that led to the emergence of democracy in Taiwan, what supported the newly-emerging democratic institutions was not a wholesale "political modernization", but a recombination of Confucian attributes in order to create a new cultural configuration. As in the English case, these changes were neither automatic nor inevitable, and again required a certain degree of cultural entrepreneurship and, of course, the ability to leverage the fluidity of Confucian culture.

\section{Conclusion}

In this paper, we have articulated a very different approach to political change than the popular and influential modernization theory. In comparison to the almost automatic link that this theory draws between economic modernization and a particular path of political institutions, we emphasized three very different dynamics. First, the dynamics of political institutions need to be accompanied 
by changes in cultural configurations - by which we mean changes in how people use existing attributes of their culture set in order to generate social meaning, coordinate expectations and manufacture justifications for various political and economic outcomes. Second, the same economic changes may strengthen despotic rule and bolster the cultural configuration that supports despotic rule in some societies, while destabilizing them and paving the way to democratization in others. History, institutions, the exact balance of power between state and society (and elites and citizens) and the nature of prevailing cultural configurations matter in determining which outcomes will ensue. Third, even when there are strong possibilities for a particular path of political institutions, like democracy, whether this will take place depends on cultural entrepreneurs proposing new cultural configurations and political entrepreneurs coordinating political action. There should be no presumption that such entrepreneurship will immediately arise or necessarily succeed even when other conditions are suitable.

We developed these ideas theoretically building and extending the framework in Acemoglu and Robinson (2019), which highlights how different state-society relations - corresponding to Despotic, Absent and Shackled leviathans - can emerge and become self-sustaining.

Moving away from the simple framework of modernization theory is not only empirically compelling, but also opens up a host of new areas for conceptual, theoretical and historical studies. For example, what are the conditions that facilitate cultural and political entrepreneurship? What aspects of the balance of power between state and society matters most for culture and politics? What types of cultural configurations will be more enduring even when challenged by new models? And how useful will these ideas be in understanding various episodes of modernization and non-modernization in history?

\section{Bibliography}

Acemoglu, Daron, Simon Johnson and James A. Robinson (2005) "The Rise of Europe: Atlantic Trade, Institutional Change and Economic Growth," American Economic Review, 95, 546579.

Acemoglu, Daron, Simon Johnson, James A. Robinson and Pierre Yared (2008) "Income and Democracy," American Economic Review, 98, 808-842.

Acemoglu, Daron, Simon Johnson, James A. Robinson and Pierre Yared (2009) "Reevaluating the Modernization Hypothesis," Journal of Monetary Economics, 56, 1043-1058.

Acemoglu, Daron and James A. Robinson (2012) Why Nations Fail, New York: Crown. 
Acemoglu, Daron and James A. Robinson (2017) "The Emergence of Weak, Despotic and Inclusive States," NBER Working Paper No. 23657.

Acemoglu, Daron and James A. Robinson (2018) "Beyond Modernization Theory", The Annals of Comparative Democratization, 16(3), 26-31.

Acemoglu, Daron and James A. Robinson (2019) The Narrow Corridor, New York: Penguin Books.

Acemoglu, Daron and James A. Robinson (2021) "Culture, Institutions and Social Equilibria: A Framework," NBER Working Paper No. 28832.

Adams, Julia (2005) The Familial State: Ruling Families and Merchant Capitalism in Early Modern Europe, Ithaca: Cornell University Press.

Almond, Gabriel A. and Sidney Verba (1963) The Civic Culture: Political Attitudes and Democracy in Five Nations, Princeton: Princeton University Press.

Anderson, Benedict (1983) Imagined Communities: Reflections on the Origin and Spread of Nationalism, London: Verso.

Apter, David E. (1967) The Politics of Modernization, Chicago: University of Chicago Press.

Banfield, Edward C. (1958) Moral Basis of a Backward Society, New York: The Free Press.

Bolt, Jutta and Jan Luiten van Zanden (2020) "The Maddison Project," https://www.rug.nl/ggdc/historicaldevelopment/maddison/publications/wp15.pdf

Chandra, Kanchan ed. (2012) Constructivist Theories of Ethnic Politics, New York: Oxford University Press.

Confucius (2003) Analects, translated by Edward Slingerland, Indianapolis: Hackett Publishing Company.

DiMaggio, Paul (1997) "Culture and cognition," Annual Review of Sociology, 23, 263-287.

Elton, Geoffrey R. (1953) The Tudor Revolution in Government: Administrative Changes in the Reign of Henry VIII, New York: Cambridge University Press.

Fei, Xiaotong (1992) From the Soil: The Foundations of Chinese Society, Berkeley: University of California Press.

Fetzer, Joel and J Christopher Soper (2012) Confucianism, Democratization, and Human Rights in Taiwan, Lanham: Lexington Books.

Flannery, Kent and Joyce Marcus (2014) The Creation of Inequality: How Our Prehistoric Ancestors Set the Stage for Monarchy, Slavery, and Empire, Cambridge: Harvard University Press.

Fukuyama, Francis (1989) "The End of History?" The National Interest, 16, 3-18.

Geertz, Clifford (1973) The Interpretation of Cultures, New York: Basic Books. 
Gellner, Ernest (2009) Nations and Nationalism, Second Edition, Ithaca: Cornell University Press.

Goldin, Paul R. (2011) Confucianism, Berkeley: University of California Press.

Gorski, Philip S. (2003) The Disciplinary Revolution: Calvinism and the Rise of the State in Early Modern Europe, Chicago: University of Chicago Press.

Grzymała-Busse, Anna (2012) "Why Comparative Politics Should Take Religion (More) Seriously," Annual Review of Political Science, 15, 421-442.

Grzymała-Busse, Anna (2015) Nations under God: How Churches Use Moral Authority to Influence Policy, Princeton: Princeton University Press.

Heldring, Leander, James A. Robinson and Sebastian Vollmer (2015) "The Long-Run Impact of the Dissolution of the English Monasteries," NBER Working Paper No. 21450.

Hindle, Steve (2000) The State and Social Change in Early Modern England, C. 1550-1640, New York: Palgrave Macmillan.

Horowitz, Donald L. (2000) Ethnic Groups in Conflict, Updated Edition, Berkeley: University of California Press.

Huntington, Samuel P. (1968) Political Order in Changing Societies, New Haven: Yale University Press.

Huntington, Samuel P. (1991) "Democracy's Third Wave," Journal of Democracy, 2, 2, $12-34$.

Huntington, Samuel P. (1996) The Clash of Civilizations and the Remaking of World Order, New York: Simon and Schuster.

Jha, Saumitra (2015) "Financial Asset Holdings and Political Attitudes: Evidence from Revolutionary England," Quarterly Journal of Economics, 130, 3, 1485-1545.

Kalyvas, Stathis N. (1996) The Rise of Christian Democracy in Europe, Ithaca: Cornell University Press.

Kharas, Homi and Meagan Dooley (2020) "China's Influence on the Global Middle Class" Brookings.

Laitin, David D. (1986) Hegemony and Culture: Politics and Religious Change among the Yoruba, Chicago: University of Chicago Press.

Laitin, David D. (1998) Identity in Formation: The Russian-Speaking Populations in the New Abroad, Ithaca: Cornell University Press.

Legge, James (1893) The Chinese Classics, Volume 1, 2nd Edition, Oxford: Oxford University Press. 
Lipset, Seymour Martin (1959) "Some Social Requisites of Democracy: Economic Development and Political Legitimacy," American Political Science Review, 53, 1, 69-105.

Machiavelli, Niccolò (1961) The Prince, New York: Penguin.

Malinowski, Bronislaw (1921) "The Primitive Economics of the Trobriand Islanders," Economic Journal, 31, 121, 1-16.

Malinowski, Bronislaw (1922) Argonauts of the Western Pacific, London: Routledge and Kegan Paul.

Malinowski, Bronislaw (1926) Crime and custom in savage society, New York: Harcourt, Brace \& Co.

Mokyr, Joel (2016) A Culture of Growth: The Origins of the Modern Economy, Princeton: Princeton University Press.

Moore, Barrington Jr. (1966) Social Origins of Dictatorship and Democracy: Lord and Peasant in the Making of the Modern World, Cambridge: Beacon Press.

Pan, Jennifer and Yiqing Xu (2017) "China's Ideological Spectrum," Journal of Politics, 80, 1 254-273.

Perry, Elizabeth J. (2008) "Chinese Conceptions of "Rights": From Mencius to Mao- and Now," Perspectives on Politics, 6, 1, 37-50.

Perry, Elizabeth J. (2018) "Cultural Governance in Contemporary China: "Re-Orienting" Party Propaganda," in To Govern China: Evolving Practices of Power edited by Vivienne Shue and Patricia M. Thornton, New York: Cambridge University Press.

Pincus, Steven C.A. (2009) 1688: The First Modern Revolution, New Haven: Yale University Press.

Posner, Daniel (2005) Institutions and Ethnic Politics in Africa, New York: Cambridge University Press.

Putnam, Robert H. (1993) Making Democracy Work, Princeton: Princeton University Press.

Rostow, Walt W. (1971) Politics and the Stages of Growth, New York: Cambridge University Press.

Ryan, Alan (2012) On Politics, Volume 1, New York: W.W. Norton \& Co.

Sewell, William (2005) Logics of History: Social Theory and Social Transformation, Chicago: University of Chicago Press.

Shang Yang (2017) The Book of Lord Shang, edited and translated by Yuri Pines, New York: Columbia University Press. 
Skinner, Quentin (1978) The Foundations of Modern Political Thought: Volume 2 The Age of Reformation, New York: Cambridge University Press.

Sommerville, Johann P. (1999) Royalists and Patriots: Politics and Ideology in England 1603-1640, New York: Longman.

Steinmetz, George ed. (1999) State/Culture: State-Formation after the Cultural Turn, Ithaca: Cornell University Press.

Swidler, Ann (1986) "Culture in Action: Symbols and Strategies," American Sociological Review, 51, 2, 273-286.

Tawney, R.H. (1941) "The Rise of the Gentry, 1558-1640," Economic History Review, 11, 1, $1-38$.

Tilly, Charles (1990) Coercion, Capital and European States, Oxford: Blackwell.

Treisman, Daniel (2020) "Economic Development and Democracy: Predispositions and Triggers," Annual Review of Political Science, 23, 241-257.

Vile, M. J. C. (1967) Constitutionalism and the Separation of Powers, New York: Oxford University Press.

Weber, Max (1951) The Religion of China: Confucianism and Taoism, New York: The Free Press.

Wickham, Chris (2016) Medieval Europe, New Haven: Yale University Press.

Wolin, Sheldon (2004) Politics and Vision, Princeton: Princeton University Press. 